\title{
Halobacillus campisalis sp. nov., containing meso- diaminopimelic acid in the cell-wall peptidoglycan, and emended description of the genus Halobacillus
}

Correspondence Jung-Hoon Yoon jhyoon@kribb.re.kr

\author{
Jung-Hoon Yoon, So-Jung Kang, Yong-Taek Jung and Tae-Kwang Oh
}

Korea Research Institute of Bioscience and Biotechnology (KRIBB), PO Box 115, Yusong, Taejon, Korea

\begin{abstract}
A Gram-positive or variable, motile and coccoid or oval-shaped bacterial strain, ASL-17 ${ }^{\top}$, was isolated from a marine solar saltern of the Yellow Sea in Korea and its exact taxonomic position was investigated by a polyphasic approach. Strain ASL-17 $7^{\top}$ grew optimally at $\mathrm{pH} 7.0-8.0$ and $37{ }^{\circ} \mathrm{C}$. Phylogenetic analysis based on $16 \mathrm{~S}$ rRNA gene sequences showed that strain ASL-17 ${ }^{\top}$ is most closely affiliated phylogenetically to the genus Halobacillus. Strain ASL-17 $7^{\top}$ exhibited $16 \mathrm{~S}$ rRNA gene sequence similarity values of $97.7-98.6 \%$ to the type strains of recognized Halobacillus species. Interestingly, strain ASL-17 ${ }^{\top}$ had cell-wall peptidoglycan based on meso-diaminopimelic acid, unlike other Halobacillus species. It contained MK-7 as the predominant menaquinone. The major fatty acids were anteiso- $C_{15: 0}$, anteiso- $C_{17: 0}$ and iso- $\mathrm{C}_{16: 0}$. The DNA G $+\mathrm{C}$ content was $42.1 \mathrm{~mol} \%$. DNA-DNA relatedness data and differential phenotypic properties demonstrated that strain ASL-17 $7^{\top}$ can be differentiated from recognized Halobacillus species. On the basis of phenotypic, chemotaxonomic, phylogenetic and genetic data, strain ASL-17 $7^{\top}$ represents a novel species of the genus Halobacillus, for which the name Halobacillus campisalis sp. nov. is proposed. The type strain is ASL-17 ${ }^{\top}$ (=KCTC $13144^{\top}$ $=$ CCUG 54360 ${ }^{\top}$ ).
\end{abstract}

The genus Halobacillus was created by Spring et al. (1996) through the reclassification of Sporosarcina halophila as Halobacillus halophilus and the description of two novel species, Halobacillus litoralis and Halobacillus trueperi. Subsequently, six further Halobacillus species, Halobacillus salinus (Yoon et al., 2003), Halobacillus karajensis (Amoozegar et al., 2003), Halobacillus locisalis (Yoon et al., 2004), Halobacillus aidingensis and Halobacillus dabanensis (Liu et al., 2005) and Halobacillus yeomjeoni (Yoon et al., 2005), have been described. In this study, we describe a bacterial strain, ASL- $17^{\mathrm{T}}$, which is related phylogenetically to the genus Halobacillus. However, strain ASL- $17^{\mathrm{T}}$ was found to have cell-wall peptidoglycan based on meso-diaminopimelic acid instead of L-ornithine, as found in other members of the genus Halobacillus. Accordingly, the aim of the present study was to determine the exact taxonomic position of strain ASL- $17^{\mathrm{T}}$ by a polyphasic characterization that included determination of the phenotypic and chemotaxonomic properties, detailed phylogenetic analysis based on 16S rRNA gene sequences and genetic analysis.

Strain ASL- $17^{\mathrm{T}}$ was isolated from a sediment collected from a marine solar saltern of the Yellow Sea, Korea, by

The GenBank/EMBL/DDBJ accession number for the $16 \mathrm{~S}$ rRNA gene sequence of strain $\mathrm{ASL}-17^{\top}$ is EF486356. means of the dilution-plating technique at $30{ }^{\circ} \mathrm{C}$ on marine agar 2216 (MA; Difco) supplemented with $8 \%$ (w/v) $\mathrm{NaCl}$. The type strains of nine Halobacillus species were used as reference strains for DNA-DNA hybridization: $H$. halophilus KCTC $3685^{\mathrm{T}}, H$. litoralis KCTC $3687^{\mathrm{T}}$ and $H$. trueperi KCTC $3686^{\mathrm{T}}$ were obtained from the Korean Collection for Type Cultures (KCTC), Taejon, Korea; $H$. karajensis DSM $14948^{\mathrm{T}}$ was obtained from the Deutsche Sammlung von Mikroorganismen und Zellkulturen (DSMZ), Braunschweig, Germany; H. salinus HSL- $3^{\mathrm{T}}, H$. locisalis MSS $-155^{\mathrm{T}}$ and $H$. yeomjeoni MSS $-402^{\mathrm{T}}$ were obtained in our laboratory (Yoon et al., 2003, 2004, 2005); and $H$. aidingensis JCM $12771^{\mathrm{T}}$ and $H$. dabanensis JCM $12772^{\mathrm{T}}$ were obtained from the Japan Collection of Microorganisms (JCM), Saitama, Japan.

The morphological, physiological and biochemical characteristics of strain ASL- $17^{\mathrm{T}}$ were investigated using routine cultivation on MA supplemented with $6 \%(\mathrm{w} / \mathrm{v})$ $\mathrm{NaCl}$ at $37{ }^{\circ} \mathrm{C}$. Cell morphology was examined by light microscopy (Nikon E600) and transmission electron microscopy. Flagellation was determined by using a Philips CM-20 transmission electron microscope with cells from exponentially growing cultures: for this purpose, the cells were negatively stained with $1 \%(\mathrm{w} / \mathrm{v})$ phosphotungstic acid and the grids were examined after being air-dried. Growth under anaerobic conditions was 
determined after incubation in a Forma anaerobic chamber on MA supplemented with $6 \%(\mathrm{w} / \mathrm{v}) \mathrm{NaCl}$ and on $\mathrm{MA}$ supplemented with $6 \%(\mathrm{w} / \mathrm{v}) \mathrm{NaCl}$ and potassium nitrate, both of which had been prepared anaerobically using nitrogen. The $\mathrm{pH}$ range for growth was determined in marine broth 2216 (MB; Difco) supplemented with $6 \%$ $(\mathrm{w} / \mathrm{v}) \mathrm{NaCl}$ that was adjusted to various $\mathrm{pH}$ values ( $\mathrm{pH} 4.5-9.5$ at intervals of $0.5 \mathrm{pH}$ units). Growth in the absence of $\mathrm{NaCl}$ was investigated using trypticase soy broth, using supplementation with $0.45 \% \quad(\mathrm{w} / \mathrm{v})$ $\mathrm{MgCl}_{2} \cdot 6 \mathrm{H}_{2} \mathrm{O}$, prepared according to the formula of the Difco medium except that $\mathrm{NaCl}$ was omitted. Growth at various $\mathrm{NaCl}$ concentrations was investigated in $\mathrm{MB}$ or trypticase soy broth (Difco). Growth at various temperatures $\left(4-50{ }^{\circ} \mathrm{C}\right)$ was measured on MA supplemented with $6 \%(\mathrm{w} / \mathrm{v}) \mathrm{NaCl}$. Catalase and oxidase activities and hydrolysis of casein, starch and Tweens 20, 40, 60 and 80 were determined as described by Cowan \& Steel (1965). Hydrolysis of hypoxanthine, tyrosine and xanthine was tested on MA supplemented with $6 \%(\mathrm{w} / \mathrm{v}) \mathrm{NaCl}$ using the substrate concentrations described by Cowan \& Steel (1965). Hydrolysis of aesculin, gelatin and urea and nitrate reduction were investigated as described previously (Lanyi, 1987) with the modification that artificial seawater supplemented with $6 \%(\mathrm{w} / \mathrm{v}) \mathrm{NaCl}$ was used for preparation of media. The artificial seawater contained $\left(1^{-1}\right.$ distilled water) $23.6 \mathrm{~g} \mathrm{NaCl}, 0.64 \mathrm{~g} \mathrm{KCl}, 4.53 \mathrm{~g}$ $\mathrm{MgCl}_{2} \cdot 6 \mathrm{H}_{2} \mathrm{O}$, $5.94 \mathrm{~g} \quad \mathrm{MgSO}_{4} \cdot 7 \mathrm{H}_{2} \mathrm{O}$ and $1.3 \mathrm{~g}$ $\mathrm{CaCl}_{2} \cdot 2 \mathrm{H}_{2} \mathrm{O}$ (Bruns et al., 2001). $\mathrm{H}_{2} \mathrm{~S}$ production was tested as described previously (Bruns et al., 2001). Susceptibility to antibiotics was investigated on MA plates supplemented with $6 \%(\mathrm{w} / \mathrm{v}) \mathrm{NaCl}$ by using antibiotic discs with the following amounts: polymyxin B, $100 \mathrm{U}$; streptomycin, $50 \mu \mathrm{g}$; penicillin G, $20 \mathrm{U}$; chloramphenicol, $100 \mu \mathrm{g}$; ampicillin, $10 \mu \mathrm{g}$; cephalothin, $30 \mu \mathrm{g}$; gentamicin, $30 \mu \mathrm{g}$; novobiocin, $5 \mu \mathrm{g}$; tetracycline, $30 \mu \mathrm{g}$; kanamycin, $30 \mu \mathrm{g}$; lincomycin, $15 \mu \mathrm{g}$; oleandomycin, $15 \mu \mathrm{g}$; neomycin, $30 \mu \mathrm{g}$; carbenicillin, $100 \mu \mathrm{g}$. Acid production from carbohydrates was tested as described by Leifson (1963) using supplementation with $7 \%(\mathrm{w} / \mathrm{v}) \mathrm{NaCl}$. Utilization of various substrates for growth was determined as described by Baumann \& Baumann (1981) using supplementation with $7 \%(\mathrm{w} / \mathrm{v}) \mathrm{NaCl}, 2 \%(\mathrm{v} / \mathrm{v})$ Hutner's mineral salts solution (Cohen-Bazire et al., 1957) and $1 \%(\mathrm{v} / \mathrm{v})$ vitamin solution (Staley, 1968). Enzyme activities were determined by using the API ZYM system (bioMérieux).

Cell biomass for DNA extraction and for analyses of cellwall and isoprenoid quinones was obtained from cultivation in $\mathrm{MB}$ supplemented with $6 \%(\mathrm{w} / \mathrm{v}) \mathrm{NaCl}$ at $37^{\circ} \mathrm{C}$. Chromosomal DNA was isolated and purified according to the method described by Yoon et al. (1996), with the exception that RNase T1 was used in combination with RNase A to minimize contamination with RNA. The $16 \mathrm{~S}$ rRNA gene was amplified by PCR using two universal primers as described previously (Yoon et al., 1998). Sequencing of the amplified 16S rRNA gene and phylogenetic analysis were performed as described by Yoon et al.
(2003). The isomer type of the diamino acid in the cell-wall peptidoglycan was analysed using TLC according to the method described by Komagata \& Suzuki (1987). Preparation of whole-cell hydrolysates and determination of the isomer type of the diamino acid was also performed at the DSMZ by using TLC and the solvent system of Rhuland et al. (1955). Isoprenoid quinones were analysed as described by Komagata \& Suzuki (1987) using reversedphase HPLC. For cellular fatty acid analysis, cell mass of strain ASL-17 ${ }^{\mathrm{T}}$ was harvested from agar plates after cultivation for 3 days at $37{ }^{\circ} \mathrm{C}$ on MA supplemented with $6 \%(\mathrm{w} / \mathrm{v}) \mathrm{NaCl}$. The fatty acids were extracted and fatty acid methyl esters were prepared according to the standard protocol of the MIDI/Hewlett Packard Microbial Identification System (Sasser, 1990). The DNA G+C content was determined by the method of Tamaoka \& Komagata (1984) with the modification that DNA was hydrolysed using nuclease P1 (Sigma) and the resultant nucleotides were analysed by reversed-phase HPLC. DNADNA hybridization was performed fluorometrically by the method of Ezaki et al. (1989) using photobiotin-labelled DNA probes and microdilution wells. Hybridization was performed with five replications for each sample. The highest and lowest values obtained in each sample were excluded, and the means of the remaining three values were quoted as DNA-DNA relatedness values.

Morphological, cultural, physiological and biochemical characteristics of strain ASL- $17^{\mathrm{T}}$ are given in the species description and in Table 1. The almost-complete 16S rRNA gene sequence of strain ASL- $17^{\mathrm{T}}$ determined in this study comprised 1522 nucleotides, representing approximately $96 \%$ of the Escherichia coli 16S rRNA gene sequence. Comparative 16S rRNA gene sequence analysis revealed that strain ASL- $17^{\mathrm{T}}$ was most closely related phylogenetically to the genus Halobacillus. In the phylogenetic tree based on the neighbour-joining algorithm, strain ASL- $17^{\mathrm{T}}$ fell within the radiation of the cluster comprising Halobacillus species, joining the type strain of $H$. halophilus with a bootstrap confidence value of $90.3 \%$ (Fig. 1). The relationship between strain ASL- $17^{\mathrm{T}}$ and the type strain of $H$. halophilus was also maintained in trees based on the maximum-likelihood and maximum-parsimony algorithms (Fig. 1). Strain ASL- $17^{\mathrm{T}}$ exhibited $16 \mathrm{~S}$ rRNA gene sequence similarity values of $97.7-98.6 \%$ to the type strains of Halobacillus species and of less than $97.1 \%$ to other species used in the phylogenetic analysis. Strain ASL- $17^{\mathrm{T}}$ had cell-wall peptidoglycan based on meso-diaminopimelic acid as the diagnostic diamino acid, unlike previously described Halobacillus species, which have cell-wall peptidoglycan based on L-Orn-D-Asp (Spring et al., 1996; Amoozegar et al., 2003; Yoon et al., 2003, 2004, 2005; Liu et al. 2005). The predominant isoprenoid quinone detected in strain ASL- $17^{\mathrm{T}}$ was menaquinone-7 (MK-7). The fatty acid profile of strain ASL- $17^{\mathrm{T}}$ was composed of the following (each constituting $>0.5 \%$ of total fatty acids): branched fatty acids anteiso- $\mathrm{C}_{15: 0}(50.8 \%)$, anteiso- $\mathrm{C}_{17: 0}(21.2 \%)$, iso- $\mathrm{C}_{16: 0}(12.5 \%)$, iso- $\mathrm{C}_{15: 0}(5.1 \%)$, iso- $\mathrm{C}_{14: 0}(3.5 \%)$ and 
Table 1. Differential phenotypic properties of Halobacillus species

Species: 1, H. campisalis sp. nov. (strain ASL-17 ${ }^{\mathrm{T}}$ ); 2, H. halophilus (data from Claus et al., 1983; Spring et al., 1996); 3, H. trueperi (Spring et al., 1996); 4, H. litoralis (Spring et al., 1996); 5, H. salinus (Yoon et al., 2003); 6, H. karajensis (Amoozegar et al., 2003); 7, H. locisalis (Yoon et al., 2004); 8, H. dabanensis (Liu et al., 2005); 9, H. aidingensis (Liu et al., 2005); 10, H. yeomjeoni (Yoon et al., 2005). +, Positive; -, negative; w, weakly positive; V, variable; ND, no data available; DAP, diaminopimelic acid. All species are positive for catalase and oxidase. All species are negative for nitrate reduction (no data for H. karajensis), urease, anaerobic growth and hydrolysis of tyrosine (no data for H. karajensis).

\begin{tabular}{|c|c|c|c|c|c|c|c|c|c|c|}
\hline Characteristic & 1 & 2 & 3 & 4 & 5 & 6 & 7 & 8 & 9 & 10 \\
\hline $\begin{array}{l}\text { Cell } \\
\text { morphology }\end{array}$ & $\begin{array}{c}\text { Cocci or } \\
\text { oval }\end{array}$ & $\begin{array}{c}\text { Cocci or } \\
\text { oval }\end{array}$ & Rods & Rods & Rods & Rods & Rods & Rods & Rods & $\begin{array}{l}\text { Rods or } \\
\text { long fila- } \\
\text { mentous } \\
\text { rods }\end{array}$ \\
\hline Flagellation & Peritrichous & $\begin{array}{l}\text { Single or } \\
\text { peritrichous }\end{array}$ & Peritrichous & Peritrichous & Peritrichous & Absent & Single & Peritrichous & Peritrichous & Single \\
\hline Spore position & Central & $\begin{array}{c}\text { Central or } \\
\text { lateral }\end{array}$ & $\begin{array}{l}\text { Central or } \\
\text { subterminal }\end{array}$ & $\begin{array}{l}\text { Central or } \\
\text { subterminal }\end{array}$ & $\begin{array}{l}\text { Central or } \\
\text { subterminal }\end{array}$ & $\begin{array}{l}\text { Central or } \\
1 \text { subterminal }\end{array}$ & $\begin{array}{l}\text { Central or } \\
\text { subterminal }\end{array}$ & $\begin{array}{l}\text { Central or } \\
\text { subterminal }\end{array}$ & $\begin{array}{l}\text { Central or } \\
\text { subterminal }\end{array}$ & $\begin{array}{c}\text { Central or } \\
\text { subter- } \\
\text { minal }\end{array}$ \\
\hline Colony colour & $\begin{array}{l}\text { Light } \\
\text { yellow }\end{array}$ & Orange & Orange & Orange & $\begin{array}{c}\text { Pale orange- } \\
\text { yellow }\end{array}$ & $\begin{array}{c}\text { Cream or } \\
\text { white }\end{array}$ & $\begin{array}{c}\text { Light orange- } \\
\text { yellow }\end{array}$ & $\begin{array}{c}\text { Cream to } \\
\text { orange }\end{array}$ & Orange & $\begin{array}{l}\text { Light } \\
\text { yellow }\end{array}$ \\
\hline Growth at $4{ }^{\circ} \mathrm{C}$ & + & - & - & - & - & - & - & - & - & - \\
\hline \multicolumn{11}{|l|}{ Growth at: } \\
\hline pH 5.0 & - & - & - & - & + & - & + & + & - & - \\
\hline pH 5.5 & + & - & - & - & + & - & + & + & - & - \\
\hline \multicolumn{11}{|l|}{ Growth at: } \\
\hline $0.5 \% \mathrm{NaCl}$ & $+^{*}$ & - & + & + & + & - & - & + & + & $+^{*}$ \\
\hline $25 \% \mathrm{NaCl}$ & - & - & + & + & - & - & - & + & - & - \\
\hline \multicolumn{11}{|l|}{ Hydrolysis of: } \\
\hline Aesculin & + & - & - & - & + & + & + & - & - & - \\
\hline Casein & + & + & - & - & + & + & - & + & + & + \\
\hline Gelatin & - & + & + & + & + & + & - & - & + & + \\
\hline Starch & + & + & - & - & - & + & + & + & + & - \\
\hline D-Glucose & + & - & + & + & + & + & + & + & + & + \\
\hline D-Mannitol & - & - & - & + & + & + & - & + & + & + \\
\hline Trehalose & + & - & + & + & + & $\mathrm{ND}$ & + & + & + & + \\
\hline Cell-wall type & meso-DAP & $\begin{array}{l}\text { L-Orn-D- } \\
\text { Asp }\end{array}$ & $\begin{array}{l}\text { L-Orn-D- } \\
\text { Asp }\end{array}$ & $\begin{array}{l}\text { L-Orn-D- } \\
\text { Asp }\end{array}$ & $\begin{array}{l}\text { L-Orn-D- } \\
\text { Asp }\end{array}$ & $\begin{array}{l}\text { L-Orn-D- } \\
\text { Asp }\end{array}$ & $\begin{array}{l}\text { L-Orn-D- } \\
\text { Asp }\end{array}$ & $\begin{array}{l}\text { L-Orn-D- } \\
\text { Asp }\end{array}$ & $\begin{array}{l}\text { L-Orn-D- } \\
\text { Asp }\end{array}$ & $\begin{array}{l}\text { L-Orn-D- } \\
\text { Asp }\end{array}$ \\
\hline $\begin{array}{c}\text { DNA G +C } \\
\text { content } \\
(\mathrm{mol} \%)\end{array}$ & 42.1 & $40.1-40.9$ & 43 & 42 & 45 & 41.3 & 44.0 & 41.4 & 42.2 & 42.9 \\
\hline
\end{tabular}

${ }^{\star}$ Positive when $\mathrm{Mg}^{2+}$ ions are added.

iso- $\mathrm{C}_{17: 0}(2.5 \%)$; unsaturated fatty acid $\mathrm{C}_{16: 1} \omega 7 c$ alcohol (1.6\%); straight-chain fatty acids $\mathrm{C}_{16: 0}(1.2 \%)$ and $\mathrm{C}_{15: 0}(0.6 \%)$; and summed feature 4 (iso- $\mathrm{C}_{17: 1}$ and/or anteiso- $\mathrm{C}_{17: 1}, 0.6 \%$ ). This fatty acid profile was similar as those of Halobacillus species, although there are differences in the proportions of some fatty acids, probably because of 


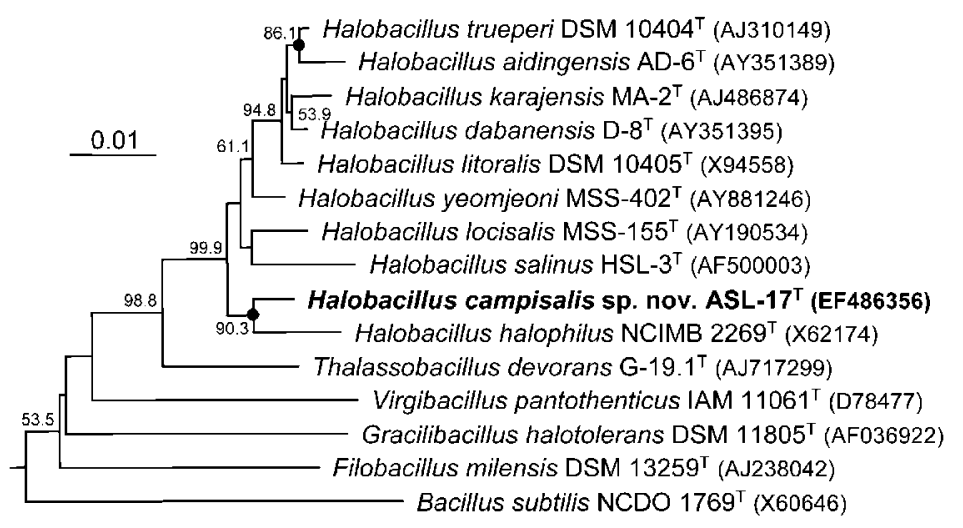

Fig. 1. Neighbour-joining phylogenetic tree based on 16S rRNA gene sequences showing the positions of strain ASL-17 ${ }^{\top}$ (Halobacillus campisalis sp. nov.), other Halobacillus species and some other related taxa. Bootstrap values (expressed as percentages of 1000 replications) $>50 \%$ are shown at branch points. Dots indicate that the corresponding nodes were also recovered in trees generated with the maximum-likelihood and maximumparsimony algorithms. Alicyclobacillus acidocaldarius DSM $446^{\top}$ (GenBank accession no. X60742; not shown) was used as an outgroup. Bar, 0.01 substitutions per nucleotide position. differences in cultivation conditions and extraction procedures (Liu et al., 2005; Yoon et al., 2005). The DNA G+C content of strain ASL-17 ${ }^{\mathrm{T}}$ was $42.1 \mathrm{~mol} \%$. Strain ASL-17 is clearly distinguishable from Halobacillus species by the difference in the cell-wall peptidoglycan type (Table 1). However, the phylogenetic similarities between strain ASL$17^{\mathrm{T}}$ and Halobacillus species may be too great to place strain ASL- $17^{\mathrm{T}}$ in a new genus separate from the genus Halobacillus. Moreover, strain ASL- $17^{\mathrm{T}}$ does not show noteworthy differences from members of the genus Halobacillus in isoprenoid quinone or fatty acid profiles. Accordingly, it appears to be appropriate that strain ASL$17^{\mathrm{T}}$ be classified in the genus Halobacillus.

Strain ASL- $17^{\mathrm{T}}$ exhibited DNA-DNA relatedness values of $11-25 \%$ to the type strains of nine recognized Halobacillus species: $H$. halophilus KCTC $3685^{\mathrm{T}}(18 \%)$, H. litoralis KCTC $3687^{\mathrm{T}}(25 \%)$, H. trueperi KCTC $3686^{\mathrm{T}}$ (12\%), $H$. karajensis DSM $14948^{\mathrm{T}}(12 \%)$, H. salinus HSL-3 ${ }^{\mathrm{T}}(19 \%)$, $H$. locisalis MSS $-155^{\mathrm{T}}(17 \%), H$. yeomjeoni MSS-402 ${ }^{\mathrm{T}}$ $(22 \%), H$. aidingensis JCM $12771^{\mathrm{T}}(11 \%)$ and $H$. dabanensis JCM $12772^{\mathrm{T}}(18 \%)$. These values indicate that strain ASL- $17^{\mathrm{T}}$ represents a genomic species that is different from recognized Halobacillus species (Wayne et al., 1987). Strain ASL- $17^{\mathrm{T}}$ can be differentiated from recognized Halobacillus species by differences in several phenotypic characteristics and in cell-wall type (Table 1). The phylogenetic and genetic distinctiveness and differential phenotypic properties are sufficient to allocate strain ASL- $17^{\mathrm{T}}$ to a species that is separate from recognized Halobacillus species (Wayne et al., 1987; Table 1). Therefore, on the basis of the data presented, strain ASL$17^{\mathrm{T}}$ should be placed within a novel species of the genus Halobacillus, for which the name Halobacillus campisalis sp. nov. is proposed.

\section{Description of Halobacillus campisalis sp. nov.}

Halobacillus campisalis (cam.pi.sa'lis. L. n. campus field; L. gen. n. salis of salt; N.L. gen. n. campisalis of a field of salt).
Cells are cocci or oval $(0.7-1.4 \times 1.0-1.6 \mu \mathrm{m})$ on MA supplemented with $6 \%(\mathrm{w} / \mathrm{v}) \mathrm{NaCl}$ at $37{ }^{\circ} \mathrm{C}$. Gram-positive, but Gram-variable in old cultures. Colonies are circular, slightly convex, smooth, glistening, light-yellow in colour and 1.5-2.0 mm after 3 days incubation at $37{ }^{\circ} \mathrm{C}$ on $\mathrm{MA}$ supplemented with $6 \%(\mathrm{w} / \mathrm{v}) \mathrm{NaCl} . \mathrm{Mg}^{2+}$ ions are required for growth. Optimal growth temperature is $37{ }^{\circ} \mathrm{C}$; growth occurs at 4 and $41{ }^{\circ} \mathrm{C}$, but not at $42{ }^{\circ} \mathrm{C}$. Optimal pH for growth is 7.0-8.0; growth occurs at $\mathrm{pH} 5.5$ but not at $\mathrm{pH} 5.0$. Optimal growth occurs in the presence of approximately $8 \%$ (w/v) $\mathrm{NaCl}$; growth occurs without $\mathrm{NaCl}$ and in the presence of $22 \%(\mathrm{w} / \mathrm{v}) \mathrm{NaCl}$, but not in the presence of $>23 \%(\mathrm{w} / \mathrm{v})$ $\mathrm{NaCl}$. Tweens 20, 40 and 60, hypoxanthine and xanthine are not hydrolysed. $\mathrm{H}_{2} \mathrm{~S}$ is not produced. In assays with the API ZYM system, alkaline phosphatase, esterase (C4), esterase lipase (C8) and $\beta$-galactosidase are present, but lipase (C14), leucine arylamidase, valine arylamidase, cystine arylamidase, trypsin, $\alpha$-chymotrypsin, acid phosphatase, naphthol-AS-BIphosphohydrolase, $\alpha$-galactosidase, $\beta$-glucuronidase, $\alpha$-glucosidase, $\beta$-glucosidase, $N$-acetyl- $\beta$-glucosaminidase, $\alpha$-mannosidase and $\alpha$-fucosidase are absent. D-Glucose, D-fructose, D-galactose, D-cellobiose, D-mannose, trehalose, sucrose and maltose are utilized, but L-arabinose, D-xylose, acetate, citrate, succinate, benzoate, L-malate, pyruvate, salicin, formate and L-glutamate are not. Acid is produced from $\mathrm{D}$-cellobiose, lactose, D-mannose, D-melezitose, melibiose, Draffinose and L-rhamnose, but not from L-arabinose, myoinositol, D-ribose or D-sorbitol. Susceptible to ampicillin, carbenicillin, cephalothin, chloramphenicol, gentamicin, kanamycin, lincomycin, neomycin, novobiocin, oleandomycin, penicillin $G$, streptomycin and tetracycline, but not to polymyxin B. The cell-wall peptidoglycan contains mesodiaminopimelic acid as the diamino acid. The predominant menaquinone is $\mathrm{MK}-7$. The major fatty acids $(>10 \%$ of total fatty acids) are anteiso- $\mathrm{C}_{15: 0}$, anteiso- $\mathrm{C}_{17: 0}$ and iso- $\mathrm{C}_{16: 0}$. The DNA G $+\mathrm{C}$ content of the type strain is $42.1 \mathrm{~mol} \%$.

The type strain, ASL- $17^{\mathrm{T}}$ (=KCTC $13144^{\mathrm{T}}=\mathrm{CCUG}$ $54360^{\mathrm{T}}$ ), was isolated from a marine solar saltern of the Yellow Sea in Korea. 


\section{Emended description of the genus Halobacillus Spring et al. 1996}

The description of the genus Halobacillus is as given by Spring et al. (1996), Yoon et al. (2003, 2004, 2005), Amoozegar et al. (2003) and Liu et al. (2005) with the following amendment. The cell-wall peptidoglycan is based on L-Orn-D-Asp or meso-diaminopimelic acid.

\section{Acknowledgements}

This work was supported by the 21C Frontier program of Microbial Genomics and Applications (grant MG05-0401-2-0) and the Support and Application Project of Biological Resources (grant M10508050004-06N0805-00410) from the Ministry of Science and Technology (MOST) of the Republic of Korea. We are grateful to Dr Peter Schumann (Identification Service of the DSMZ) for analysing the cell-wall peptidoglycan.

\section{References}

Amoozegar, M. A., Malekzadeh, F., Malik, K. A., Schumann, P. \& Spröer, C. (2003). Halobacillus karajensis sp. nov., a novel moderate halophile. Int J Syst Evol Microbiol 53, 1059-1063.

Baumann, P. \& Baumann, L. (1981). The marine Gram-negative eubacteria: genera Photobacterium, Beneckea, Alteromonas, Pseudomonas, and Alcaligenes. In The Prokaryotes, pp. 1302-1331. Edited by M. P. Starr, H. Stolp, H. G. Trüper, A. Balows \& H. G. Schlegel. Berlin: Springer-Verlag.

Bruns, A., Rohde, M. \& Berthe-Corti, L. (2001). Muricauda ruestringensis gen. nov., sp. nov., a facultatively anaerobic, appendaged bacterium from German North Sea intertidal sediment. Int $J$ Syst Evol Microbiol 51, 1997-2006.

Claus, D., Fahmy, F., Rolf, H. J. \& Tosunoglu, N. (1983). Sporosarcina halophila sp. nov., an obligate, slightly halophilic bacterium from salt marsh soils. Syst Appl Microbiol 4, 496-506.

Cohen-Bazire, G., Sistrom, W. R. \& Stanier, R. Y. (1957). Kinetic studies of pigment synthesis by nonsulfur purple bacteria. J Cell Physiol 49, 25-68.

Cowan, S. T. \& Steel, K. J. (1965). Manual for the Identification of Medical Bacteria. London: Cambridge University Press.

Ezaki, T., Hashimoto, Y. \& Yabuuchi, E. (1989). Fluorometric deoxyribonucleic acid-deoxyribonucleic acid hybridization in microdilution wells as an alternative to membrane filter hybridization in which radioisotopes are used to determine genetic relatedness among bacterial strains. Int J Syst Bacteriol 39, 224-229.
Komagata, K. \& Suzuki, K. (1987). Lipids and cell-wall analysis in bacterial systematics. Methods Microbiol 19, 161-203.

Lanyi, B. (1987). Classical and rapid identification methods for medically important bacteria. Methods Microbiol 19, 1-67.

Leifson, E. (1963). Determination of carbohydrate metabolism of marine bacteria. J Bacteriol 85, 1183-1184.

Liu, W. Y., Zeng, J., Wang, L., Dou, Y. T. \& Yang, S. S. (2005). Halobacillus dabanensis sp. nov. and Halobacillus aidingensis sp. nov., isolated from salt lakes in Xinjiang, China. Int J Syst Evol Microbiol 55, 1991-1996.

Rhuland, L. E., Work, E., Denman, R. F. \& Hoare, D. S. (1955). The behavior of the isomers of $\alpha, \varepsilon$-diaminopimelic acid on paper chromatograms. J Am Chem Soc 77, 4844-4846.

Sasser, M. (1990). Identification of bacteria by gas chromatography of cellular fatty acids, Technical Note 101. Newark, DE: MIDI Inc.

Spring, S., Ludwig, W., Marquez, M. C., Ventosa, A. \& Schleifer, K.-H. (1996). Halobacillus gen. nov., with description of Halobacillus litoralis sp. nov. and Halobacillus trueperi sp. nov., and transfer of Sporosarcina halophila to Halobacillus halophilus comb. nov. Int J Syst Bacteriol 46, 492-496.

Staley, J. T. (1968). Prosthecomicrobium and Ancalomicrobium: new prosthecate freshwater bacteria. J Bacteriol 95, 1921-1942.

Tamaoka, J. \& Komagata, K. (1984). Determination of DNA base composition by reversed-phase high-performance liquid chromatography. FEMS Microbiol Lett 25, 125-128.

Wayne, L. G., Brenner, D. J., Colwell, R. R., Grimont, P. A. D., Kandler, O., Krichevsky, M. I., Moore, L. H., Moore, W. E. C., Murray, R. G. E. \& other authors (1987). International Committee on Systematic Bacteriology. Report of the ad hoc committee on reconciliation of approaches to bacterial systematics. Int J Syst Bacteriol 37, 463-464.

Yoon, J.-H., Kim, H., Kim, S.-B., Kim, H.-J., Kim, W. Y., Lee, S. T., Goodfellow, M. \& Park, Y.-H. (1996). Identification of Saccharomonospora strains by the use of genomic DNA fragments and rRNA gene probes. Int J Syst Bacteriol 46, 502-505.

Yoon, J.-H., Lee, S. T. \& Park, Y.-H. (1998). Inter- and intraspecific phylogenetic analysis of the genus Nocardioides and related taxa based on 16S rDNA sequences. Int J Syst Bacteriol 48, 187-194.

Yoon, J.-H., Kang, K. H. \& Park, Y.-H. (2003). Halobacillus salinus sp. nov., isolated from a salt lake on the coast of the East Sea in Korea. Int J Syst Evol Microbiol 53, 687-693.

Yoon, J.-H., Kang, K. H., Oh, T.-K. \& Park, Y.-H. (2004). Halobacillus locisalis sp. nov., a halophilic bacterium isolated from a marine solar saltern of the Yellow Sea in Korea. Extremophiles 8, 23-28.

Yoon, J.-H., Kang, K. H., Oh, T.-K. \& Park, Y.-H. (2005). Halobacillus yeomjeoni sp. nov., isolated from a marine solar saltern in Korea. Int $J$ Syst Evol Microbiol 55, 2413-2417. 